\title{
Persepsi Nasabah Terhadap Praktik Produk Pembiayaan Murabahah BNI Syariah Cabang Banda Aceh
}

\author{
Rachmatina, Dedi Sufriadi \\ Universitas Islam Negeri Ar-Raniry Banda Aceh
}

Naskah diterima 24 Maret 2020, Revisi 30 Maret 2020, Terbit 19 April 2020

\begin{abstract}
Abstrak
DOI: doi.org/10.21107/pamator.v13i1.6983

Penelitian ini bertujuan untuk mengetahui bagaimana pengaruh persepsi nasabah terhadap praktik produk pembiayaan murabahah di bank BNI Syariah Cabang Banda Aceh. Teknik pengumpulan data dilakukan dengan menyebarkan kuesioner kepada 40 nasabah pembiayaan murabahah BNI Syariah Banda Aceh. Teknik pengambilan sampel menggunakan purposive sampling. Penelitian ini merupakan penelitian kuantitatif dengan alat analisis data regresi linear sederhana dengan bantuan software SPSS versi 22. Hasil penelitian ini menunjukkan bahwa persepsi nasabah berpengaruh terhadap praktik produk pembiayaan murabahah sebesar 19,7\% sedangkan 80,3\% yang dipengaruhi oleh variabel lain yang tidak dimasukkan dalam penelitian ini. Oleh karena itu, bank diharapkan dapat meningkatkan penerapan praktik produk pembiayaan murabahah untuk meningkatkan persepsi nasabah yang baik terhadap produk pembiayaan murabahah.
\end{abstract}

Kata Kunci : pembiayaan, murabahah, syariah, bank

\section{PENDAHULUAN}

Bank syariah adalah suatu lembaga keuangan yang berfungsi sebagai perantara bagi pihak yang kelebihan dana dengan pihak yang kekurangan dana untuk kegiatan usaha dan kegiatan lainnya sesuai dengan hukum Islam. (Ali, 2010). Tugas bank syariah yaitu untuk menghimpun dana masyarakat serta menyalurkannya dengan mekanisme syariah. Penghimpunan dana bank syariah yang dilakukan melalui simpanan dan investasi seperti: giro, wadiah, tabungan dan deposito berjangka. Sedangkan penyaluran dana dilakukan dengan beberapa akad yaitu murabahah, istishna, mudharabah, musyarakah, ijarah, dan salam. Berdasarkan berbagai macam produk pembiayaan perbankan syariah, murabahah merupakan salah satu bentuk pembiayaan yang paling dominan diterapkan dalam praktik perbankan syariah (Wiroso, 2005).

Standar Operasional Produk (SOP) pembiayaan murabahah pada bank syariah didasarkan pada Keputusan Fatwa DSN Nomor 04/DSN-MUI/IV/2000 dan berdasarkan Peraturan Bank Indonesia (PBI) Nomor 9/19/PBI/2007 jo Surat Edaran BI No. 10/14/DPbS tanggal 17 Maret 2008.

Ada tiga model atau tipe penerapan jual beli murabahah di perbankan. Pertama, tipe konsisten terhadap fiqih muamalah. Dalam tipe ini bank membeli dahulu barang yang akan dibeli oleh nasabah setelah ada perjanjian sebelumnya. Setelah barang dibeli atas nama bank kemudian dijual ke nasabah dengan harga perolehan ditambah margin keutungan sesuai kesepakatan bank dan nasabah. Kedua, mirip dengan tipe yang pertama, tapi perpindahan kepemilikan langsung dari supplier kepada nasabah, sedangkan pembayaran dilakukan bank langsung kepada penjual pertama/supplier. Ketiga, bank melakukan perjanjian murabahah dengan nasabah, dan pada saat yang mewakilkan kepada nasabah untuk membeli sendiri barang yang akan dibelinya. Dari ketiga tipe tersebut, tipe kedua dan tipe ketiga paling sering dipakai oleh bank syariah karena motifasi efektifitas prosedur dan juga pertimbangan efisiensi terutama dari pengenaan pajak pertambahan nilai. Sementara tipe pertama justru dihindari padahal tipe inilah yang paling ideal dalam konteks fiqh muamalah (Muammar, 2016).

$\begin{array}{ccc}\text { Salah satu bank syariah yang } \\ \text { menerapkan } & \text { produk pembiayaan }\end{array}$ murabahah yaitu bank BNI Syariah. Bank BNI Syariah menerapkan produk pembiayaan murabahah karena lebih mudah dan aman, sehingga prinsip kehati-hatian bank syariah lebih mudah terjaga. Jumlah 
nasabah yang menggunakan produk pembiayaan murabahahpada bank BNI Syariah mengalami peningkatan dari tahun ke tahun (Tabel 1).

Tabel 1. Pembiayaan Murabahah BNI Syariah Cabang Banda Aceh

\begin{tabular}{cc}
\hline Tahun & Jumlah Nasabah \\
\hline 2014 & 300 \\
2015 & 324 \\
2016 & 376 \\
2017 & 427 \\
\hline \multicolumn{2}{l}{ Sumber: BNI Syariah Cabang Banda Aceh, 2018 }
\end{tabular}

Pada Tabel 1 di atas dapat dilihat bahwa jumlah nasabah pembiayaan murabahah BNI Syariah mengalami peningkatan setiap tahunnya dari tahun 2014 sampai 2017. Pada tahun 2014 terdapat 300 nasabah, kemudian di tahun 2015 bertambah menjadi 324 nasabah. Pada tahun berikutnya yaitu tahun 2016 nasabah BNI Syariah yang mengambil pembiayaan murabahah bertambah menjadi 376 hingga 427 nasabah ditahun 2017.

Ada sejumlah alasan kenapa murabahah begitu populer dalam operasional pembiayaan pada bank syariah adalah : (1) murabahah adalah suatu mekanisme investasi jangka pendek, dan dibandingkan dengan profit and loss sharing cukup memudahkan; (2) mark-up dalam murabahah dapat ditetapkan demikian rupa sehingga memastikan bahwa bank dapat memperoleh keuntungan yang sebanding dengan keuntungan bank-bank berbasis bunga yang menjadi saingan bank-bank Islam; (3) murabahah menjauhkan dari ketidakpastian yang ada pada pendapatan bisnis-bisnis dengan sistem profit and loss sharing; (4) murabahah tidak memungkinkan bank-bank Islam untuk mencampuri manajemen bisnis, karena bukanlah mitra si nasabah, sebab hubungan mereka dalam murabahah adalah hubungan hutangpiutang dagang (Sofiyah, 2015).

Dalam kegiatan operasionalnya, bank BNI Syariah tentunya tidak luput dari permasalahan dalam pembiayaan. Hal tersebut dapat dilihat dari laporan keuangan Bank BNI Syariah bagian Non Performing Financing (NPF) pada empat tahun terakhir. Pada tahun 2014, pembiayaan produktif komersial di BNI Syariah berhasil tumbuh dengan baik, dengan menjaga posisi NPF yang terkendali dari sebesar $3,04 \%$ pada tahun sebelumnya 2013 menjadi sebesar $0,00 \%$ pada tahun 2014. Pada pembiayaan konsumer di tahun 2014 tingkat pembiayaan bermasalah BNI Syariah relatif rendah yaitu sebesar 1,32\% dibandingkan dengan tahun sebelumnya yang berada pada $1,38 \%$. Sedangkan dalam pembiayaan ritel produktif BNI Syariah berhasil tumbuh secara terkendali, terbukti dengan NPF yang berada pada posisi 3,46\%.

Menjadi permasalahan bukan pada akadnya, karena murabahah diakui secara syariah, yang menjadi masalah adalah terjadi penyimpangan dalam praktik akad murabahah, yang mengakibatkan akad tersebut batil secara syariah. Adapun penyimpangan secara umum terjadi pada bank syariah pada pelanggaran syarat murabahah, yaitu syarat kepemilikan terhadap harta (milkiyah) dan harga awal yang diketahui (ra'ul mal ma'lum), penempatan akad murabahah pada transaksi yang salah, misalnya pembiayaan untuk renovasi rumah, tidak bisa dilakukan dengan akad murabahah, karena tidak terpenuhinya syarat milkiyah (kepemilikan) dan ra'sul mal (modal) yang diketahui. Seharusnya akad yang tepat pada jenis tersebut adalah akad istisna paralel. Dalam istisna' harga ditentukan diawal transaksi, namun tidak ada syarat ra'sul mal ma'lum dan ar-ribb ma'lum, kemudian serah terima barang terjadi setelah barang selesai, melibatkan maysir dalam perhitungan margin keuntungan, perbankan syariah melibatkan inflasi dalam menentukan margin keuntungannya. Tentu ini sangat bertentangan dengan syariah, tingkat inflasi di masa depan merupakan sesuatu yang tidak pasti. Bermain dengan ketidakpastian merupakan bentuk dari maysir (Sulaiman, 2016).

Meskipun demikian, mekanisme pembiayaan murabahah ini, ternyata tak lepas dari kecaman dan kritikan dari para ilmuwan muslim sendiri. Mereka berpendapat bahwa bank-bank syariah dalam menjalankan kegiatan usahanya, ternyata bukannya meniadakan bunga, tetapi tetap mempertahankan praktek pembebanan bunga, namun dengan label 'Islam' (Sjahdeini, 1999).

Masalah yang telah dijelaskan di atas tentang pelaksanaan produk murabahah dalam perbankan syariah menimbulkan 
persepsi. Persepsi yang kurang baik dari masyarakat terhadap perbankan syariah yaitu masyarakat beranggapan bahwa praktik bank syariah tidak berbeda dengan praktik bank konvensional mengenai pembiayaan dan bagi hasil dengan tingkat suku bunga yang berlaku umum ( $B I$ rate atau LIBOR). Apabila kesalahan persepsi ini dibiarkan akan mengakibatkan masyarakat tidak bisa lagi membedakan bank sistem syariah dan bank sistem konvensional. Praktik murabahah yang dilakukan oleh perbankan syariah masih menuai kritikan karena dianggap sama dengan kredit pada perbankan konvensional. Hal ini dilihat dari besarnya margin yang dipatok bank syariah yang ternyata sama atau bahkan lebih tinggi dibandingkan dengan bunga bank konvensional. Tingginya margin ini disebabkan oleh pangsa pasar bank syariah yang masih sangat kecil. Agar bisa bersaing, maka ditetapkanlah margin yang sangat tinggi. Penetapan besaran margin yang sangat tinggi inilah yang kemudian menciptakan persepsi negatif terhadap produk bank syariah. Persepsi negatif tidak hanya akan mempengaruhi citra produk dan jasa bank syariah tetapi juga citra perusahaan dan semuanya akan berdampak pada reputasi bank syariah. Juga akan berdampak pula terhadap minat nasabah untuk berinvestasi pada bank syariah (Acfira, 2014).

Alasan mengapa penulis memilih penelitian di Bank BNI Syariah salah satunya dikarenakan Bank BNI Syariah merupakan salah satu bank syariah yang tingkat kemajuannya cukup baik. Dilansir dari website resmi BNI Syariah, perkembangannya cukup pesat dapat dilihat dari catatan pada bulan Juni 2014 jumlah cabang BNI Syariah mencapai 65 Kantor Cabang, 161 Kantor Cabang Pembantu, 17 Kantor Kas, dan 20 Payment Point. Bank BNI Syariah berdiri pertama kali dengan modal dasar sebesar Rp 4.004.000.000.000 dan modal ditempatkan dan disetor penuh sebesar Rp 1.501.500.000.000.

\section{METODOLOGI}

\section{Jenis dan Pendekatan Penelitian}

Jenis penelitian dalam penelitian ini adalah menggunakan penelitian kuantitatif. Penelitian kuantitatif adalah penelitian menghasilkan data yang berbentuk angka atau bilangan. Sesuai dengan bentuknya, data kuantitatif dapat diolah atau dianalisis menggunakan teknik perhitungan matematika atau statistika (Suryana, 2010). Pendekatan penelitian ini menggunakan pendekatan lapangan (field research). Pendekatan lapangan merupakan suatu penelitian di mana untuk mengumpulkan data serta informasi peneliti yang akan terjun langsung ke objek penelitian seperti menyebarkan kuesioner kepada responden yang kemudian data tersebut diolah dan dianalisis kembali (Suwartono, 2014).

\section{Lokasi penelitian}

Penelitian ini mengambil tempat penelitian pada Bank BNI Syariah Cabang Banda Aceh yang beralamat di JL. Daud Beureueh No.33, Laksana, Kuta Alam, Kota Banda Aceh, Aceh 24415.

\section{Data dan Teknik Pengumpulan Data}

Jenis data yang digunakan dalam penelitian ini yaitu data primer. Data primer dalam penelitian ini diperoleh dengan mengumpulkan data secara langsung dari hasil penyebaran kuisioner yang diberikan kepada responden Bank BNI Syariah Cabang Banda Aceh.

\section{Populasi dan Sampel Penelitian}

Populasi adalah keseluruhan subjek penelitian. Apabila seseorang ingin meneliti semua elemen yang ada dalam wilayah penelitian, maka penelitiannya merupakan penelitian populasi. Populasi juga diartikan sebagai wilayah generalisasi yang terdiri atas objek/subjek yang mempunyai karakteristik tertentu dan mempunyai kesempatan yang sama untuk dipilih menjadi anggota sampel (Umar, 2011). Populasi yang digunakan dalam penelitian ini adalah nasabah yang menggunakan produk pembiayaan murabahah di Bank BNI Syariah Cab Banda Aceh yang berjumlah 1427 orang.

Sampel adalah bagian dari jumlah dan karakteristik yang dimiliki oleh populasi sehingga sifat dan karakteristik populasi juga dimiliki oleh sampel (Sugiyono, 2011). Metode pengambilan sampel dalam penelitian ini adalah menggunakan teknik non-probability dengan teknik Purposive Sampling, suatu teknik penentuan sampel 
dengan pertimbangan tertentu (Sugiyono, 2012). Dalam teknik sampling ini, yang diambil sampel adalah khusus nasabah yang menggunakan produk pembiayaan murabahah.

Menurut Roscoe dalam penetapan jumlah sampel jika dalam penelitian akan melakukan analisis regresi, maka jumlah anggota sampel minimal 10 kali dari jumlah variabel yang akan diteliti. Sehingga dalam penelitian ini jumlah sampel ditentukan lebih dari batas minimal yaitu 20 kali dari jumlah variabel yang akan diteliti. Dikarenakan jumlah variabel dalam penelitian ini ada 2 (dua), maka sampel yang digunakan sebanyak $20 \times 2=40$ orang dari nasabah pembiayaan murabahah di bank BNI Syariah Cabang Banda Aceh (Sukirman, 2011).

\section{Teknik Pengumpulan Data}

Teknik pengumpulan data yang digunakan dalam penelitian ini adalah penelitian lapangan (field research), atau dapat pula disebut sebagai penelitian empiris, yaitu penelitian yang data dan informasinya diperoleh dari kegiatan dilapangan tempat peneliti melakukan penelitian (Supardi, 2005). Metode yang digunakan adalah kuesioner. Kuesioner diberikan kepada nasabah pembiayaan murabahahbank BNI Syariah Cabang Banda Aceh.

\section{Skala Pengukuran}

Skala pengukuran adalah peraturan penggunaan notasi bilangan dalam pengukuran. Pada penelitian ini, instrumen yang digunakan adalah kuesioner. Skala pengukuran dalam kuesioner dengan menggunakan skala ordinal.

Tabel 2. Skor pada Skala Likert

\begin{tabular}{ccc}
\hline Jawaban & Kode & Skor \\
\hline Sangat Tidak & STS & 1 \\
Setuju & TS & 2 \\
Tidak Setuju & KS & 3 \\
Kurang Setuju & S & 4 \\
Setuju & SS & 5 \\
Sangat Setuju &
\end{tabular}

Sumber : Siregar (2013).

Skala ordinal adalah suatu skala di mana penomoran objek/ kategori dimulai dari tingkat terendah ke tingkat tertinggi atau sebaliknya (Siregar, 2013). Karena data yang diperoleh bentuk ordinal, maka skala pengukuran yang digunakan dalam penelitian ini adalah Skala Likert (Tabel 2).

\section{Metode Analisis Data}

Metode yang digunakan untuk menganalisis data variabel penelitian adalah uji regresi sederhana. Metode regresi sederhana adalah model regresi yang digunakan jika variabel yang diteliti adalah satu. Analisis ini digunakan untuk menguji bagaimana pengaruh masing-masing variabel independent $(X)$ terhadap variabel dependen (Y). Rumus regresi linier sederhana untuk penelitian ini adalah :

$$
Y=a+b X+e
$$

Keterangan :

$X$ : Persepsi nasabah

$\mathrm{Y}$ : Produk pembiayaan murabahah

a : konstanta

$X$ : Persepsi nasabah

b : Koefisien regresi

e : Error term

\section{HASIL DAN PEMBAHASAN}

\section{Karakteristik Responden}

Responden dari penelitian ini adalah nasabah pembiayaan murabahah sebanyak 40 nasabah, kuesioner dibagikan kepada setiap responden yang dijumpai langsung di BNI Syariah Cabang Banda Aceh. Gambaran umum profil responden disajikan dalam beberapa tabel berikut :

Tabel 3. Karakteristik Responden Berdasarkan Jenis Kelamin

\begin{tabular}{cccc}
\hline No & Jenis Kelamin & Frequency & Percent \\
\hline 1 & Laki-Laki & 25 & 62,5 \\
\hline 2 & Perempuan & 15 & 37,5 \\
\hline & Total & $\mathbf{4 0}$ & $\mathbf{1 0 0 , 0}$
\end{tabular}

Berdasarkan Tabel 3 di atas, dapat disimpulkan bahwa sebagian besar responden dalam penelitian adalah laki-laki sebanyak 25 orang atau $62,5 \%$ dan selebihnya adalah perempuan 15 orang atau $37,5 \%$. Hal ini menunjukkan bahwa laki-laki adalah konsumen yang lebih potensial dalam menggunakan pembiayaan murabahah di BNI Syariah cabang Banda Aceh, karena tugas seorang laki-laki sebagai kepala keluarga yang harus mencukupi kebutuhan keluarganya, meliputi kebutuhan primer, sekunder dan tersier. 
Adapun data mengenai usia responden nasabah pembiayaan murabahah BNI Syariah, adalah :

\begin{tabular}{cccc}
$\begin{array}{l}\text { Tabel } \\
\text { Berdasarkan Usia }\end{array}$ & $\begin{array}{c}\text { Karakteristik } \\
\text { Berdan }\end{array}$ & Responden \\
\hline No & Usia & Frequency & Percent \\
\hline 1 & $20-30$ tahun & 5 & 12,5 \\
2 & $31-40$ tahun & 12 & 30,0 \\
3 & $41-50$ tahun & 16 & 40,0 \\
4 & $>50$ tahun & 7 & 17,5 \\
& Total & $\mathbf{4 0}$ & $\mathbf{4 0}$ \\
\hline
\end{tabular}

Berdasarkan Tabel 4 di atas, dapat disimpulkan bahwa responden yang berusia 41-50 tahun lebih dominan dengan rincian 16 orang $(40 \%)$, responden dengan rentang usia 20-30 tahun sebanyak 5 orang (12,5\%), responden dengan rentang usia 31-40 tahun sebanyak 12 orang (30\%) dan responden yang usia diatas 50 tahun sebanyak 7 orang $(17,5 \%)$. Data mengenai pekerjaan responden nasabah pembiayaan murabahah BNI Syariah, adalah:

Tabel 5. Karakteristik Responden Berdasarkan Pekerjaan

\begin{tabular}{cccc}
\hline No & Usia & Frequency & Percent \\
\hline 1 & PNS & 12 & 30,0 \\
2 & Karyawan Swasta & 15 & 37,5 \\
3 & Pengusaha & 8 & 20,0 \\
4 & Lain-lain & 5 & 12,5 \\
& Total & Total & $\mathbf{4 0}$ \\
\hline
\end{tabular}

Berdasarkan Tabel 5 di atas, responden dalam penelitian ini lebih dominan karyawan swasta yaitu sebanyak 15 orang $(37,5 \%)$, Pegawai Negeri Sipil sebanyak 12 orang $(30,0 \%)$, pengusaha sebanyak 8 orang $(20,0 \%)$ dan lain-lain sebanyak 5 orang $(12,5 \%)$.

Tabel 6. Karakteristik Responden Berdasarkan Pendapatan

\begin{tabular}{|c|c|c|c|}
\hline No & Pendapatan & Frequency & Percent \\
\hline 1 & $\begin{array}{c}\text { Rp } 1.000 .000- \\
\operatorname{Rp} 2.000 .000\end{array}$ & 6 & 15,0 \\
\hline 2 & $\begin{array}{c}\operatorname{Rp} 2.100 .000- \\
\operatorname{Rp} 3.000 .000\end{array}$ & 10 & 25,0 \\
\hline 3 & $\begin{array}{c}\operatorname{Rp} 3.100 .000- \\
\operatorname{Rp} 4.000 .000\end{array}$ & 16 & 40,0 \\
\hline 4 & $\begin{array}{l}>\text { Rp } 4.000 .000 \\
\text { Total }\end{array}$ & $\begin{array}{c}8 \\
\text { Total }\end{array}$ & $\begin{array}{c}20,0 \\
40\end{array}$ \\
\hline
\end{tabular}

Tabel 7. Karakteristik Responden Berdasarkan Lama Menjadi Nasabah Pembiayaan Murabahah

\begin{tabular}{cccc}
\hline No & $\begin{array}{c}\text { Lama Menjadi } \\
\text { Nasabah } \\
\text { Pembiayaan } \\
\text { Murabahah }\end{array}$ & Frequency & Percent \\
\hline 1 & $<1$ tahun & 14 & 35,0 \\
2 & $1-2$ tahun & 8 & 20,0 \\
3 & $3-4$ tahun & 10 & 25,0 \\
4 & $>4$ tahun & 8 & 20,0 \\
& Total & Total & $\mathbf{4 0}$ \\
\hline
\end{tabular}

Berdasarkan Tabel 7 di atas, dapat disimpulkan bahwa sebanyak 14 orang (35\%) baru dibawah 1 tahun menjadi nasabah pembiayaan murabahah BNI Syariah Cabang Banda Aceh, yang sudah menjadi nasabah pembiayaan murabahahBNI Syariah Cabang Banda Aceh selama 1-2 tahun dan diatas 4 tahun keduanya sebanyak 8 orang (20\%), dan yang sudah menjadi nasabah pembiayaan murabahah BNI Syariah Cabang Banda Aceh selama 3-4 tahun sebanyak 10 orang (25\%).

\section{Persamaan Regresi Linear Sederhana}

Sebelum melakukan pengujian hipotesis, terlebih dahulu dilakukan analisis regresi sederhana. Analisis ini dilakukan untuk melihat berapa besar pengaruh yang diberikan oleh persepsi nasabah terhadap praktik produk pembiayaan murabahah BNI Syariah Cabang Banda Aceh. Adapun analisis regresi sederhana dengan bantuan SPSS Statistic Version 22.0, seperti terlihat pada Tabel 8.

Tabel 8. Persamaan Regresi Linear Sederhana

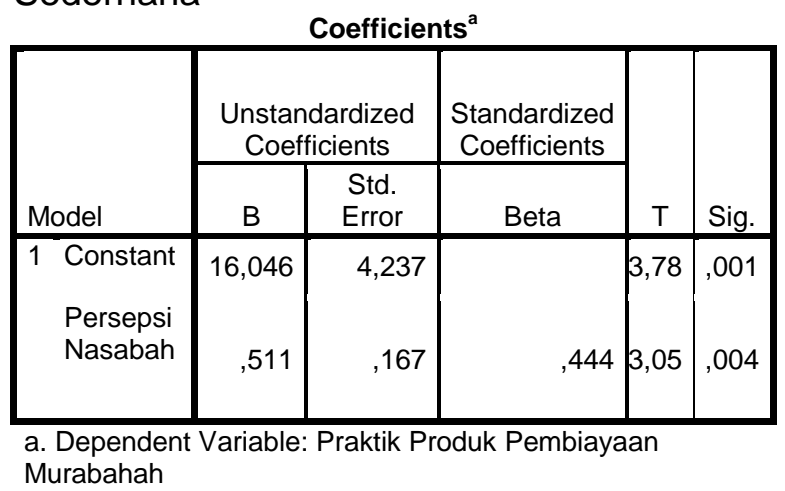

Berdasarkan Tabel 8 di atas, dapat dilihat terdapat nilai koefisien regresi. Pada kolom Unstandardized Coefficients terdapat nilai constants sebesar 16,046 
dan nilai koefisien arah regresi sebesar 0,511 . Maka dapat ditulis persamaan rumus sebagai berikut:

$$
\begin{gathered}
Y=a+b X \\
Y=16,046+0,511 X
\end{gathered}
$$

Persamaan di atas, dapat diartikan sebagai berikut:

a. Konstanta sebesar 16,046, menyatakan bahwa jika variabel persepsi nasabah $(X)$ nilainya adalah konstan, maka variabel praktik produk pembiayaan murabahah (Y) nilainya positif sebesar 16,046.

b. Koefisien regresi variabel persepsi nasabah $(X)$ sebesar 0,511 , menyatakan bahwa jika persepsi nasabah mengalami kenaikan 1 rupiah maka praktik produk pembiayaan murabahah akan meningkat sebesar 0,511 rupiah. Koefisien bernilai positif artinya terdapat hubungan positif antara persepsi nasabah dengan praktik produk pembiayaan murabahah. Semakin bertambah jumlah persepsi nasabah maka semakin tinggi praktik produk pembiayaan murabahah.

Hasil yang diperoleh dalam penelitian ini adalah persepsi nasabah mempunyai pengaruh positif dan signifikan terhadap praktik produk pembiayaan murabahah di bank BNI Syariah Cabang Banda Aceh yang ditunjukkan dengan hasil beberapa uji pengujian. Berdasarkan uji $t$ terdapat pengaruh antara persepsi nasabah terhadap praktik produk pembiayaan murabahah bank BNI Syariah Cabang Banda Aceh, dimana nilai signifikansi menunjukkan 0,004 $<0,05$ dan nilai $t_{\text {hitung }}$ sebesar 3,055 lebih besar dari nilai $t_{\text {tabel }}$ sebesar 1,685. Dengan demikian $\mathrm{H}_{\mathrm{o}}$ ditolak dan $\mathrm{H}_{\mathrm{a}}$ diterima, yang artinya terdapat pengaruh antara persepsi nasabah terhadap praktik produk pembiayaan murabahah.

Berdasarkan hasil $R^{2}$ diketahui hasil sebesar 0,197 sehingga dapat disimpulkan persepsi nasabah mempengaruhi praktik produk pembiayaan murabahah bank BNI Syariah Cabang Banda Aceh sebesar 19,7\% dan sisanya $(100 \%-19,7 \%)=80,3 \%$ yang dipengaruhi oleh variabel lain yang tidak ada dimasukkan dalam penelitian ini. Dengan rendahnya hasil pengaruh persepsi nasabah terhadap praktik produk pembiayaan murabahahmenunjukkan kepercayaan nasabah terhadap praktik produk pembiayaan murabahah relatif kecil. Oleh karena itu, bank diharapkan dapat meningkatkan penerapan praktik produk pembiayaan murabahah yang mana hal tersebut dimaksudkan untuk meningkatkan persepsi nasabah yang baik terhadap produk pembiayaan murabahah.

Terkait persamaan pada uji regresi linear sederhana dapat diartikan bahwa apabila persepsi nasabah ditingkatkan sebesar $1 \%$, maka praktik produk pembiayaan murabahah akan meningkat sebesar 0,511 atau $51,1 \%$. Apabila nilai persepsi nasabah dimisalkan 0 (tetap) maka nilai produk pembiayaan murabahah adalah sebesar 16,046 .

\section{KESIMPULAN}

Persepsi nasabah merupakan tanggapan atau pandangan terhadap praktik produk pembiayaan murabahahyang diterapkan oleh BNI Syariah Cabang Banda Aceh. Persepsi nasabah tentang praktik produk pembiayaan murabahah yang baik akan meningkatkan pengambilan pembiayaan, karena nasabah mengerti dan memahami bahwa produk pembiayaan murabahahtidak menggunakan sistem bunga yang dilarang oleh agama Islam. Hasil penelitian ini sejalan dengan penelitian Dede Nurdiansyah (2009) dan Ulul Albab (2018) yang menyatakan bahwa persepsi nasabah berpengaruh terhadappembiayaan murabahah. Sedangkan tidak sejalan dengan penelitian Okta Rizka (2017) yang menyatakan persepsi nasabah tidak berpengaruh positif $d$ an signifikan terhadap produk pembiayaan murabahah.

Disarankan kepada BNI Syariah Cabang Banda Aceh untuk terus meningkatkan praktik pada produk pembiayaan murabahah. Pihak bank juga harus memberikan pemahaman yang lebih baik lagi kepada nasabah mengenai pembiayaan murabahah mengenai tata cara pembiayaan maupun prosedur dalam pengajuan pembiayaan. Untuk peneliti selanjutnya sebaiknya dapat menambah variabel atau indikator baru dalam penelitian yang akan datang agar dapat menghasilkan gambaran yang lebih luas tentang masalah penelitian yang sedang diteliti. 


\section{DAFTAR PUSTAKA}

Al-Quran dan Terjemahannya.

Acfira, L. 2014. Pengaruh Persepsi Nasabah Terhadap Pengambilan Pembiayaan Murabahah (Studi Kasus Nasabah BNI Syariah Cab.Makassar). Skripsi Fakultas Ekonomi dan Bisnis Islam UIN Alauddin Makassar.

Albab, U. 2018. Pengaruh Persepsi Pembiayaan Murabahah dan Margin Terhadap Pengambilan Pembiayaan Murabahah di Baitu tamwil Tamzis Cab. Prambanan. Skripsi. Universitas Islam Indonesia.

Ali, Z. 2010. Hukum Perbankan Syariah. Jakarta:Sinar Grafika.

Antonio, M.S. 2000. Bank Syariah: Suatu Pengenalan Umum. Jakarta: Tazkia Institute.

Antonio, M.S. 2001. Bank Syariah: Dari Teori ke Praktek. Jakarta: Gema Insani Press.

Fadla, M. 2017. Analisis Kepatuhan Syariah Pada BNI Syariah, Bank Syariah Mandiri dan Bank Muamalat Indonesia. Bogor. Skripsi Fakultas Ekonomi dan Manajemen Institut Pertanian Bogor.

Firsan, N. 2011. Crisis Public Relation: Strategi PR Menghadapi Krisis, Mengelola Isu, Membawa Citra, dan Reputasi Perusahaan. Jakarta: Rajawali Pers

Hay, S. 2014. Strategi Keunggulan Bersaing PT Bank BNI Syariah Cabang Dharmawangsa Surabaya dalam Meningkatkatkan Jumlah Nasabah. Skripsi Universitas Islam Negeri Sunan Ampel Surabaya.

Irwanto. 2002. Psikologi Umum. Jakarta: Prenhallindo

Ismail. 2011. Perbankan Syariah. Jakarta: Kencana Prenada Media Group.

Karim, A. 2013. Bank Islam Analisis Fiqh dan Keuangan. Jakarta: IIIT Indonesia.

Kotler, P. 2008. Manajemen Pemasaran, Analisis, Perencanaan, Implementasi dan Pengendalian. Jakarta: Erlangga.

Machfudz, M. 2014. Metode Penelitian Ekonomi. Malang: Genius Media

Muammar. 2016. Teori dan Aplikasi Penerapan Akad Murabahah. Makalah. Dikutip dari muammaremere.blogspot.com/2016/ 06/teori-dan-aplikasi-penerapanakad.html?m=1.30 Desember.

Muhammad. 2011. Audit dan Pengawasan Syariah Pada Bank Syariah. Yogyakarta: UII Press.

Muhammad. 2014. Manajemen Dana Bank Syariah. Jakarta: PT. Raja GrafindoPersada

Mutaqodim, B.R. 2015. Pengaruh Penerapan Prinsip Good Corporate Terhadap Kinerja Keuangan Pegawai Perbankan Syariah Di Kabupaten Pendeglang. Jakarta. Skripsi UIN Syarif Hidayatullah

Nurdiansyah, D. 2008. Persepsi Nasabah Terhadap Produk Pembiayaan Murabahah BPRS Al Salam. Skripsi Universitas Islam Negeri Syarif Hidayatullah. Jakarta.

Priyatno, D. 2011. SPSS AnalisisStatistik Data Lebih Cepat Lebih Akurat. Yogyakarta: Medikomm.

Rakhmat, J. 2004. Psikologi Komunikasi. Bandung: PT. Rosdakarya.

Rahmawaty, A. 2014. Pengaruh Persepsi Tentang Bank Syariah Terhadap Minat Menggunakan Produk di BNI Syariah Semarang. Jurnal Agama, Teologi \& Filsafat (ADDIN), Vol. 8. No. 1, Februari 2014:1-28.

Rizka, O. 2017. Pengaruh Persepsi Nasabah dan Margin Terhadap Keputusan Pengambilan Griya Pada Bank Syariah Mandiri KCP Teluk Betung Bandar Lampung. Skripsi Fakultas Ekonomi dan Bisnis Islam UIN Rafen Intan.

Sjahdeini, S. 1999. Perbankan Islam dan Kedudukannya dalam Tata Hukum Perbankan Indonesia. Jakarta: Pustaka Utama Garfiti. 
Siregar, S. 2004. Metode Penelitian Kuantitatif dilengkapi dengan Perbandingan Perhitungan Awal SPSS. Jakarta.

Sholihin. 2010. Buku Pintar Ekonomi Syariah,Gramedia PustakaUtama.

Suryana. 2010. Metodelogi Penelitian. Universitas Pendidikan Indonesia

Suwartono. 2014. Dasar - Dasar Metodelogi Penelitian. Yogyakarta: CV Andi Offset.

Toha, M. 2003. Kepemimpinan Dalam Manajemen. Yogyakarta: Gajah Mada University.

Umar, H. 2011. Metodelogi Penelitian untuk Skripsi dan Tesis Bisnis. Jakarta: PT Raja Grafindo Persada.
Walgito, B. 2004. Psikologi Sosial: Suatu Pengantar. Yogyakarta: Fakultas Psikologi.

Wiroso. 2005. Jual Beli Murabahah. Yogyakarta: UII Press.

Zuardi, M. H. 2013. Persepsi Nasabah Terhadap Sistem Pembiayaan Bagi Hasil Di Bank Jabar Syariah Kota Cirebon. Jurnal Tapis Vol. XIII, No. 01 Januari-Juni, 7.

Zulkifili, S. 2003. Panduan Praktis Transaksi Perbankan Syariah. Jakarta: Zikrul Hakim 